\title{
A Defunct Lead-Acid Battery Recycling May Lead Strong Soil Pollution: A Case of Study in Mexico
}

\author{
Rogelio Carrillo-González ${ }^{1}$, Alejandro Ruiz-Olivares ${ }^{1}$, Ma del Carmen A González-Chávez¹, Martha \\ Reyes-Ramos ${ }^{3}$ and Javier Suarez-Espinosa ${ }^{2}$
}

${ }^{1}$ Edaphology Department, Colegio de Postgraduados, México

${ }^{2}$ Statistics Department, Colegio de Postgraduados, México

${ }^{3}$ Universidad Autónoma Chapingo, México

\begin{abstract}
Inadequate waste management from the lead-acid battery recycling (LABR) industry can severely pollute the soil. This work aimed to assess heavy metal contamination of a defunct LABR site in Mexico. Total, DTPA-extractable, water-soluble metal concentrations and soil fractionation were analyzed. Speciation of $\mathrm{Na}$ and $\mathrm{Pb}$ was calculated by Geochemist's workbench 10 Software package based on soil solution analysis. Spatial distribution of soil features are presented in maps by the Kriging method. Total $\mathrm{Pb}$ and $\mathrm{Cu}$ concentrations reached up to $474,105 \mathrm{mg} \mathrm{kg}^{-1}$ and $3,911 \mathrm{mg} \mathrm{kg}^{-1}$, respectively, representing the greatest risk at the site. The highest DTPA-extractable Pb concentration was $12,000 \mathrm{mg}$ $\mathrm{kg}^{-1}$, and the water-soluble $\mathrm{Pb}$ was $4.5 \mathrm{mg} \mathrm{kg}^{-1}$. High concentrations of available $\mathrm{PO}_{4}^{3-}\left(1,354 \mathrm{mg} \mathrm{kg}^{-1}\right), \mathrm{SO}_{4}^{2-}(34,086 \mathrm{mg}$ $\left.\mathrm{kg}^{-1}\right)$ and $\mathrm{Na}\left(33,101 \mathrm{mg} \mathrm{kg}^{-1}\right)$ were found. Lead fraction decreased as follow: Exchangeable $\left(284,580 \mathrm{mg} \mathrm{kg}^{-1}\right)>$ bound on to sulfides $>$ weakly bound to $\mathrm{OM}>$ bound onto $\mathrm{Fe}$ and $\mathrm{Mn}$ oxides $>$ residual phase $>$ strongly bound to $\mathrm{OM}$. The predominant chemical species in soil solution were $\mathrm{Pb}^{2+}$ (up to $86 \%$ ) and $\mathrm{Na}^{+}(99 \%)$.
\end{abstract}

\section{Keywords}

Lead distribution, Copper, Salinity, Lead speciation

\section{Introduction}

Lead-acid batteries (LAB) are widely used for many industries and are the source of electric energy in every single vehicle. $L A B$ are built with metal grids ( $25 \%$ to $30 \%$ of their weight), electrode paste ( $35 \%$ to $45 \%$ ), sulfuric acid solution ( $10 \%$ to $15 \%)$, connectors and poles of $\mathrm{Pb}$ alloy, grid separators made up of PVC ( $5 \%$ to $8 \%$ ), ebonite ( $1 \%$ to $3 \%$ ) and a plastic case. $\mathrm{LAB}$ cells are composed of a $\mathrm{Pb}$ electrode (anode) and $\mathrm{a} \mathrm{Pb}$ oxide electrode (cathode) immersed in a solution of sulfuric acid, metallic grids and connections [1], for this reason, used-batteries are considered as hazardous waste.

Lead-acid battery recycling ( $L A B R$ ) attempts to recover $\mathrm{Pb}$ and plastic from old batteries. In the USA, $99 \%$ of the LAB is recycled, because the efficiency of $\mathrm{Pb}$ recovery in 1990 was up to $95 \%$ [2]. Globally, $80 \%$ of the $\mathrm{Pb}$ produced is destined for $\mathrm{LAB}$ manufacturing and $95 \%$ of $\mathrm{Pb}$ used in batteries comes from the recycling process. Lead recycling has economic and ecological advantages but some disadvantages, one disadvantage is the release of $\mathrm{Pb}$ to the environment. $\mathrm{A}$ fraction of the $\mathrm{Pb}$ from batteries remains in the produced sludge as $\mathrm{PbSO}_{4}, \mathrm{PbO}_{2}$, and $\mathrm{PbO} \mathrm{PbSO}_{4}[3]$, which can be disposed in the soil. Therefore, inadequate LABR process and residue disposal may seriously pollute soil and groundwater [4] as occur in some developing countries. Hence, workers engaged in LABR are frequently exposed to contaminants because they often manipulate the material by hand without safety equipment [5]. Lead is considered as the second priority risk substance at sites in the USA National Priorities List [6]. The world most seriously polluted sites (in 2012 and 2015) are commonly related to the LABR industry and $\mathrm{Pb}$ deposition $[5,7]$.

The present research involves the soil of a LABR factory which was closed by the Mexican Environmental Agency (MEA), due to complaints from residents of the neighborhood. This agency suspected high $\mathrm{Pb}$ concentrations in soil. Nevertheless, there were no reports, files or other available

*Corresponding author: Rogelio Carrillo-González, Soil and Environmental Chemistry Lab, Colegio de Postgraduados, km 36.5 Carretera México-Texcoco. 56230, Mexico, Tel: +525558045900, Email: crogelio@colpos.mx

Accepted: June 22, 2019

Published online: June 24, 2019

Citation: Carrillo-González R, Ruiz-Olivares A, González-Chávez MCA, et al. (2019) A Defunct Lead-Acid Battery Recycling May Lead Strong Soil Pollution: A Case of Study in Mexico. J Soil Water Sci 3(1):75-83 
information about the procedure used for recycling neither the batteries nor the protocol for waste management. As a result, the MEA needs an environmental assessment of the defunct LABR site.

Precise information about the distribution and dynamics of the pollutants in the soil is required to define a remediation strategy. This study aimed to assess the concentrations of metals and salts and their spatial variability in the soil at a defunct LABR factory site located in Tepetlaoxtoc, Mexico.

\section{Materials and Methods}

\section{Soil sampling}

The study area is located at central Mexico (19.550831, -98.794714) in a former recycling factory of lead-acid batteries; the factory was near to the Hondo creek. The soil survey was carried out using a systematical sampling procedure [8]. A grid of $5 \times 5 \mathrm{~m}$ was laid out and at each intercept composite soil samples $(5-20 \mathrm{~cm}$ depth) were taken (a total of 54 samples). Six additional composite non-polluted soil samples were taken near to the LABR site to determine natural soil heavy metal concentrations.

\section{Fertility and soil solution analyses}

Immediately after soil collection, oxide-reduction potential (ORP) was measured in soil samples in a 1: 2.5 soil: Water ratio slurry with a $\mathrm{pH}$ meter (Thermo Orion $420 \mathrm{~A}$ ) using an ORP electrode. The equipment was calibrated using Light's solution [9]. After ORP determination, the soil was air-dried and sieved $(\leq 2 \mathrm{~mm})$ before other analyses.

Soil samples were air dried and sieved for the analysis of soil features, $\mathrm{Pb}$ and $\mathrm{Cu}$ concentrations. Plant available nutrients: Phosphorus [10], sulfate-[11] and $\mathrm{N}(\mathrm{KCl}$ extraction and Kjeldahl distillation) [12] were measured. Besides, total carbonates was determined by the calcimeter method [13] and organic matter (OM) by the loss on ignition procedure [14].

Electrical conductivity (EC), $\mathrm{pH}$ and oxide reduction potential (ORP) were measured as mentioned above in liquid extracts from saturation pastes (soil solution) [15]. The water-soluble ions were determined: $\mathrm{SO}_{4}{ }^{2-}$ (modified 9038 method) [16], $\mathrm{PO}_{4}{ }^{3-}[10], \mathrm{HCO}_{3}^{-}, \mathrm{CO}_{3}{ }^{2-}, \mathrm{Ca}$ and $\mathrm{Mg}$ [17], $\mathrm{Cl}, \mathrm{Na}$ and $\mathrm{K}$ (argentometric and flame photometrically methods) [18]. Analysis of $\mathrm{PO}_{4}^{3-}$ and $\mathrm{SO}_{4}{ }^{2-}$ in this section differs from those determined in Section 2.2.1, as the soil solution contains soluble compounds which react in the liquid phase of the soil.

Heavy metal concentrations were also determined in the soil solution before chemical speciation simulation, mimicking the soil solution reactions. Sodium adsorption (SAR) and potassium adsorption (PAR) ratios were calculated to determine the relationship between $\mathrm{Na}^{+}, \mathrm{K}^{+}, \mathrm{Ca}^{2+}$, and $\mathrm{Mg}^{2+}$ as follows:

$$
\text { (1) } S A R: \frac{N a^{+}}{\sqrt{\frac{C a^{2+}+\mathrm{Mg}^{2+}}{2}}} \text { (2) } P A R: \frac{K^{+}}{\sqrt{\frac{C a^{2+}+\mathrm{Mg}^{2+}}{2}}}
$$

Where: $\mathrm{Na}^{+}, \mathrm{K}^{+}, \mathrm{Ca}^{2+}$ and $\mathrm{Mg}^{2+}$ are the concentrations of these cations (milliequivalents $\mathrm{L}^{-1}$ ).

\section{Heavy metal soil concentrations}

Total metal concentrations were determined after acid digestion in $\mathrm{HNO}_{3}-\mathrm{HClO}_{4}-\mathrm{H}_{2} \mathrm{O}_{2}$ (3:1:1) mixture (modified 3050B) [19]. The extractable metals were determined with DTPA-TEA- $\mathrm{CaCl}_{2}$ solution (DTPA-extractable) in a 1:5 soil: Solution ratio [20]. Bioavailability index [21] of the metals was calculated as follows: [(DTPA-TEA-CaCl ${ }_{2}$ extractable concentration/total metal concentration)*100]. Saturated paste extract was prepared to measure the soluble salts and metals in soil.

Fractionation of metals was analyzed by sequential extraction following the Pagnanelli modified method [22]. The fractions obtained were: Exchangeable $\left({ }_{\mathrm{Ex}}\right)$; bound onto $\mathrm{Fe}$ and $\mathrm{Mn}$ oxides $\left({ }_{\mathrm{FeMn}}\right)$; weakly bound to OM ( $\left.{ }_{\text {woM }}\right)$; firmly bound to $\mathrm{OM}\left({ }_{\mathrm{SOM}}\right)$ and linkedto sulfide phase $\left({ }_{\mathrm{S}}\right)$. The last stage of the fractionation was the residual fraction $\left(_{R}\right)$ : Acid digestion of the samples with $5 \mathrm{~mL}$ of $\mathrm{HNO}_{3}-\mathrm{HClO}_{4}-\mathrm{H}_{2} \mathrm{O}_{2}(3: 1: 1)$ mixture. Metals were quantified by flame atomic absorption spectrometry (Perkin Elmer model 3110).

\section{Geostatistical analysis}

Standarized semivariogram was calculated to describe the way the spatial variation of $\mathrm{Pb}$ and $\mathrm{Cu}$ soil concentrations changes along the distance separation any two points varies. Ordinary block Kriging was used to estimate the values at unsampled places, and their validations were performed with semivariograms. Graphic representations of $\mathrm{Pb}$ and $\mathrm{Cu}$ concentration in all the terrain were generated (Figure 1). The statistical package used was R 3.1.3 with the libraries gstat, $\mathrm{sp}$, maptools, gr Devices and raster [23].

\section{Data analysis}

To evaluate the potential risk of $\mathrm{Pb}, \mathrm{Cu}$ and $\mathrm{Cd}$ accumulated in the top soil, the potential mobile fractions (PMF) weakly bound to soil components was calculated. High values suggested the tendency entering to the food chain.

$$
P M F=\frac{F_{E x}}{\sum_{1}^{5} \text { Fractions }} \times 100
$$

Speciation in saturation paste extracts was carried out simulating the soil solution using Geochemist's Work bench 10 software. Correlations were performed with Spearman or Pearson method depending on the assumptions satisfied by the variables. $P$-values were used to validate these correlations. The statistical software used was R 3.1.3 [23].

\section{Results}

Contrasting to the landscape, the soil was completely naked, even this very close to the river; no vegetation was growing, with salt spots on the soil surface.

\section{Soil chemical properties}

Soil $\mathrm{pH}$ was alkaline, where $68 \%$ of the samples had $\mathrm{pH}$ $>7$ and $9 \% \mathrm{pH}>8.5$ (Table 1). The ground showed oxidizing conditions (ORP: $300-600 \mathrm{mV}$; Figure S1).The soil was saline $\left(\mathrm{EC}>4 \mathrm{dS} \mathrm{m}^{-1}\right)$. In high proportion (55\%) of the samples the $\mathrm{PO}_{4}{ }^{3-}, \mathrm{SO}_{4}{ }^{2-}, \mathrm{Cl}^{-}$and $\mathrm{Na}^{+}$concentrations were high, contributing to the EC increment. Taking into account SAR and EC values at 
Citation: Carrillo-González R, Ruiz-Olivares A, González-Chávez MCA, et al. (2019) A Defunct Lead-Acid Battery Recycling May Lead Strong Soil Pollution: A Case of Study in Mexico. J Soil Water Sci 3(1):75-83

Table 1: Salt concentrations and electrochemical properties in soil solution (saturation extracts) from a defunct LABR site. The proportions of samples exceeding recommended values are presented in brackets.

\begin{tabular}{|l|l|l|l|l|l|}
\hline Variable & Recommended & Value in soil & Variable & Recommended & Value in soil (mg L-1) \\
\hline $\mathrm{pH}$ & $6.5-7.0$ & $6.0-9.4(68 \%)^{\mathrm{a}}$ & $\mathrm{Mg}^{2+}$ & See PAR and SAR & $0-119$ \\
\hline $\left.\mathrm{EC}(\mathrm{dS} \mathrm{m})^{-1}\right)$ & $<4$ & $0.3-65.3(56 \%)^{\mathrm{a}}$ & $\mathrm{Cl}^{-}$ & $<10 \mathrm{mg} \mathrm{L}^{-1}$ & $44.3-8.050(47 \%)^{\mathrm{a}}$ \\
\hline $\mathrm{ORP}(\mathrm{mV})$ & - & $212-374$ & $\mathrm{CO}_{3}{ }^{2-}$ & - & $0-552$ \\
\hline $\mathrm{PO}_{4}{ }^{3-}\left(\mathrm{mg} \mathrm{L}^{-1}\right)$ & - & $4.1-7.2$ & $\mathrm{HCO}_{3}^{-}$ & - & $0-420$ \\
\hline $\mathrm{SO}_{4}{ }^{-2}\left(\mathrm{mg} \mathrm{L}^{-1}\right)$ & 57 & $88-47.130(100 \%)^{\mathrm{a}}$ & $\mathrm{Na}^{+}$ & SAR $<12$ & $74-33.101(94 \%)^{\mathrm{b}}$ \\
\hline $\mathrm{Ca}^{2+}\left(\mathrm{mg} \mathrm{L}^{-1}\right)$ & See PAR and SAR & $1-178$ & $\mathrm{~K}^{+}$ & PAR $=6-8$ & $2-256(100 \%)^{\mathrm{c}}$ \\
\hline
\end{tabular}

$\mathrm{n}=34$, terrain surface $=1024 \mathrm{~m}^{2}$.

EC: Electrical conductivity.

ORP: Oxidation reduction potential

SAR: Sodium adsorption ratio.

PAR: Potassium adsorption ratio.

aPercentage of samples above the average in soil solution according to normal values presented by Marschner and Rengel [24].

bPercentage of samples above the maximum recommended SAR value [31].

'Percentage of samples outside the recommended PAR value [25].

Table 2: Metal concentrations $\left(\mathrm{mg} \mathrm{kg}^{-1}\right)$ and percentage (in brackets) of soil metal fractions of the defunct LABR site in Mexico.

\begin{tabular}{|c|c|c|c|c|c|c|c|}
\hline Fraction & $\mathrm{Pb}$ & $\mathrm{Cu}$ & Mn & Zn & Cd & $\mathrm{Fe}$ & $\mathrm{Ni}$ \\
\hline \multirow[t]{2}{*}{ EX } & $5.666-284.580$ & $0-248$ & $11-156$ & $1-1.984$ & $0-11$ & $1-268$ & $2-63$ \\
\hline & $(43-97)$ & $(0-35)$ & $(6-31)$ & $(0-85)$ & $(0-63)$ & $(0-3)$ & $(8-44)$ \\
\hline \multirow[t]{2}{*}{ FeMn } & $59-46.278$ & $0-15$ & $30-221$ & $2-339$ & $0-16$ & $74-30.130$ & $7-181$ \\
\hline & $(0-21)$ & $(0-63)$ & $(27-69)$ & $(2-46)$ & $(0-40)$ & $(2-51)$ & $(17-46)$ \\
\hline \multirow[t]{2}{*}{ wOM } & $45-73.642$ & $2-18$ & $3-95$ & $1-132$ & $0-5$ & $6-21.335$ & $1-62$ \\
\hline & $(0-30)$ & $(5-90)$ & $(1-17)$ & $(3-70)$ & $(2-37)$ & $(0-53)$ & $(3-44)$ \\
\hline \multirow[t]{2}{*}{ SOM } & $33-7.506$ & $0-1.063$ & $0-1$ & $0-24$ & $0-3$ & $1-13$ & $2-7$ \\
\hline & $(0-0.2)$ & $(0-25)$ & $(0-1)$ & $(0-4)$ & $(3-29)$ & $(0-0)$ & $(1-16)$ \\
\hline \multirow[t]{2}{*}{$\mathbf{S}$} & $1.494-147.690$ & $5-1.757$ & $8-168$ & $7-194$ & $0-19$ & $1.442-19.554$ & $1-90$ \\
\hline & $(2-39)$ & $(2-74)$ & $(8-34)$ & $(3-42)$ & $(8-34)$ & $(7-94)$ & $(3-30)$ \\
\hline \multirow[t]{2}{*}{$\mathbf{R}$} & $64-30.555$ & $0-1.063$ & $25-250$ & $9-65$ & $1-5$ & $27-10.629$ & $2-29$ \\
\hline & $(0-22)$ & $(1-13)$ & $(7-36)$ & $(1-73)$ & $(8-35)$ & $(1-62)$ & $(4-21)$ \\
\hline Total & $10.792-444.105$ & 9-3.911 & $94-696$ & $24-2.337$ & $5-57$ & $2.133-59.606$ & $24-408$ \\
\hline Total NP & $306 \pm 30$ & $5 \pm 2$ & $33 \pm 9$ & $18 \pm 1$ & $3 \pm 2$ & $1.000 \pm 374$ & $28 \pm 12$ \\
\hline Kabata-Pendias ${ }^{1}$ & 27 & $14-109$ & $411-550$ & $60-89$ & 0.41 & 35,000 & $13-37$ \\
\hline Kabata-Pendias² & $50-300$ & $60-500$ & - & $200-1.500$ & $2-20$ & - & $75-150$ \\
\hline
\end{tabular}

EX: Exchangeable; FeMn: Bound onto Fe and Mn oxides; WOM: Weakly bound to organic matter; SOM: Strongly bound to organic matter; S: Bound to sulfide phase; R: Bound to the residual phase.

Total NP: Soil heavy metal concentrations in the non-polluted surrounding area of the LABR site.

${ }^{1}$ Normal total soil concentrations of elements [32].

${ }^{2}$ Maximum allowable total concentrations for heavy metals in agricultural soils [32].

the LABR site, $57 \%$ of the soil surface was saline-sodic; $34 \%$ is sodic and only $9 \%$ was not affected by salts nor $\mathrm{Na}$ (Table 1 ).

Organic matter (OM) content varied from $0.8 \%$ to $13.4 \%$. The carbonate content was from $0.2 \%$ to $3.6 \%$; the highest concentrations were found on the eastern part of the site. Plant-available $\mathrm{PO}_{4}^{3-}$ and $\mathrm{SO}_{4}^{2-}$ were detected in high concentrations; they ranged from 19 to $1,354 \mathrm{mg} \mathrm{kg}^{-1}$ and 3.8 to $34,086 \mathrm{mg} \mathrm{kg}^{-1}$, respectively. Available $\mathrm{N}$ was low in all sam- ples, from $0 \mathrm{mg} \mathrm{kg}^{-1}$ to $5 \mathrm{mg} \mathrm{kg}^{-1}$ of $\mathrm{NH}_{4}^{+}$and from $0 \mathrm{mg} \mathrm{kg}^{-1}$ to $5 \mathrm{mg} \mathrm{kg}^{-1}$ of $\mathrm{NO}_{2}^{-}+\mathrm{NO}_{3}^{-}$. However, $\mathrm{NH}_{4}^{+}$was detected only in samples from the north part of the field. The site reaction was alkaline and have poor fertility [24,25].

\section{Total heavy metal concentrations}

The total metal concentration decreased as follows $\mathrm{Pb}>\mathrm{Fe}>\mathrm{Cu}>\mathrm{Zn}>\mathrm{Mn}>\mathrm{Ni}>\mathrm{Cd}$ (Table 2). These values were higher 
than the concentrations of the non-polluted sites in the vicinity of the LABR site; and up to 1,451, 782, 19 and 15 times for $\mathrm{Pb}, \mathrm{Cu}, \mathrm{Cd}$, and $\mathrm{Ni}$, respectively (Figure $\mathrm{1a}$ ). The soil is polluted with $\mathrm{Pb}, \mathrm{Fe}, \mathrm{Cu}$ and $\mathrm{Zn}$. Apparently, these elements were introduced as a result of the dispersion of the battery slurry (Figure 1).

\section{Heavy metal fractionation}

The highest $\mathrm{Pb}$ concentrations were observed in the exchangeable fraction (Table 2). The general sequence in soil fractions decreased in the following order: $\mathrm{Pb}_{\mathrm{Ex}}>\mathrm{Pb}_{\mathrm{S}}>\mathrm{Pb}_{\text {woM }}$ $>\mathrm{Pb}_{\mathrm{FeMn}}>\mathrm{Pb}_{\mathrm{R}}>\mathrm{Pb}_{\text {SOM }}$. Exchangeable $\mathrm{Pb}$ was spatially distributed with a pattern similar to total $\mathrm{Pb}$ concentrations. Lead concentration decreased gradually from the south to the north side of the site (Figure $1 \mathrm{a}$, Figure $1 \mathrm{~b}$ and Table 2 ).

Positive correlations of $\mathrm{Pb}_{E X}$ with $\mathrm{SO}_{4}^{2-}(0.528, \mathrm{p}=0.024)$, $\mathrm{PO}_{4}{ }^{3-}(0.749, \mathrm{p}=0.001)$ and $\mathrm{OM}(0.641, \mathrm{p}=0.004)$ were found. Strongly bound to $\mathrm{OM} \mathrm{Pb}$ was correlated positively with $\mathrm{pH}$ $(0.492, \mathrm{p}=0.039)$ and similarly $\mathrm{Pb}_{\mathrm{FeMn}}$ with $\mathrm{SO}_{4}^{2-}(0.510, \mathrm{p}=$ $0.024)$. $\mathrm{Pb}_{\text {wom }}$ ranged from $0.1 \%$ to $31.6 \%$. In contrast, low concentration of $\mathrm{Pb}_{\text {SOM }}$ was observed ( $<2 \%$ of total $\mathrm{Pb}$ ).

Copper concentrations showed the following distribution: $\mathrm{Cu}_{\mathrm{S}}>\mathrm{Cu}_{\text {WOM }}>\mathrm{Cu}_{\mathrm{FeMn}}>\mathrm{Cu}_{\mathrm{R}}>\mathrm{Cu}_{\mathrm{EX}}>\mathrm{Cu}_{\mathrm{SOM}}$. A positive correlation was found between $\mathrm{Cu}_{\mathrm{EX}}$ and soil OM content $(0.71, \mathrm{p}=$ $0.001)$; $\mathrm{Cu}_{\mathrm{FeMn}}$ with $\mathrm{OM}(0.72, \mathrm{p}=0.001)$ and with $\mathrm{SO}_{4}{ }^{2-}(0.79$, $\mathrm{p}=0.001)$. Similarly, $\mathrm{Cu}_{\mathrm{SOM}}$ was correlated with $\mathrm{OM}$ content $(0.67, \mathrm{p}=0.002)$ and $\mathrm{Cu}_{\mathrm{s}}$ with $\mathrm{SO}_{4}{ }^{2-}$ concentrations $(0.680, \mathrm{p}$ $=0.001)$.

Concentrations of $\mathrm{Cd}$ decreased as follows: $\mathrm{Cd}_{\mathrm{S}}>\mathrm{Cd}_{\mathrm{FeMn}}>\mathrm{Cd}_{\mathrm{EX}}>\mathrm{Cd}_{\text {WOM }}=\mathrm{Cd}_{\mathrm{R}}>\mathrm{Cd}_{\mathrm{SOM}}$; where $\mathrm{Cd}_{\mathrm{EX}}$ was up to $63 \%$ of the total $\mathrm{Cd}$. Concentrations of $\mathrm{Fe}$ and $\mathrm{Mn}$ forming oxides $\left(\mathrm{Fe}_{\mathrm{FeMn}}\right.$ and $\left.\mathrm{Mn}_{\mathrm{FeMn}}\right)$ varied from 74 to $30,130 \mathrm{mg} \mathrm{kg}^{-1}$ for Fe and 30 to $221 \mathrm{mg} \mathrm{kg}^{-1}$ for $\mathrm{Mn}$. Up to $21 \%$ and $63 \%$ of total $\mathrm{Pb}$ and $\mathrm{Cu}$ was bound to $\mathrm{Fe}$ and $\mathrm{Mn}$ oxides (Table 2).

Nickel concentration in soil fractions decreased as follows $\mathrm{Ni}_{\text {FeMn }}>\mathrm{Ni}_{\mathrm{S}}>\mathrm{Ni}_{\mathrm{Ex}}>\mathrm{Ni}_{\text {WOM }}>\mathrm{Ni}_{\mathrm{R}}>\mathrm{Ni}_{\text {SOM. }}$. The $\mathrm{Zn}$ concentration followed this order: $\mathrm{Zn}_{\mathrm{EX}}>\mathrm{Zn}_{\mathrm{FeMn}}>\mathrm{Zn}_{\mathrm{WOM}}>\mathrm{Zn}_{\mathrm{S}}>\mathrm{Zn}_{\mathrm{R}}>\mathrm{Zn}_{\mathrm{SOM}}$, where $Z \mathrm{n}_{\mathrm{EX}}$ ranged from 24 to $2,337 \mathrm{mg} \mathrm{kg}^{-1}$.

\section{DTPA-extractable metals}

DTPA-extractable concentrations were variable: $\mathrm{Pb}$ concentrations varied from 154 to $12,000 \mathrm{mg} \mathrm{kg}^{-1}$ and $\mathrm{Cu}$ ranged from 0.01 to $1,936 \mathrm{mg} \mathrm{kg}^{-1}$, with similar distribution patterns (Figures $1 \mathrm{c}$ and Figure $1 \mathrm{~d}$ ). The highest values were at the south of the site. DTPA-extractable $\mathrm{Cu}$ concentrations correlated negatively with $\mathrm{OM}$ contents $(-0.722, \mathrm{p}=0.005)$. Bioavailability index ranged $1 \%$ to $66 \%$ for $\mathrm{Pb}, 1 \%$ to $54 \%$ for $\mathrm{Cu}$, $1 \%$ to $25 \%$ for $\mathrm{Zn}, 1 \%$ to $8 \%$ for $\mathrm{Ni}, 0 \%$ to $10 \%$ for $\mathrm{Mn}, 0 \%$ to $25 \%$ for $\mathrm{Cd}$ and $0 \%$ to $0.4 \%$ for Fe. Besides, bioavailability index of $\mathrm{Pb}$ was negatively correlated with OM $(-0.570, \mathrm{p}=$ 0.021). Low concentrations of DTPA-extractable Fe, Mn, Zn, $\mathrm{Ni}$, and $\mathrm{Cd}$ were found in all samples; soluble concentrations of $\mathrm{Mn}, \mathrm{Zn}, \mathrm{Fe}$ and $\mathrm{Cu}$ in some samples were lower than detection limits.

\section{Chemical speciation of $\mathrm{Pb}$ and $\mathrm{Na}$ in the soil solution}

Soluble $\mathrm{Pb}$ concentrations ranged from 0.024 to $4.650 \mathrm{mg}$ $\mathrm{kg}^{-1}$, where higher concentrations were detected in the southern part of the site (Figure 1e). The $\mathrm{Pb}^{2+}$ ion was present in all $\mathrm{pH}$ values tested and was the predominant species at low $\mathrm{pH}$. $\mathrm{SO}_{4}{ }^{2-}, \mathrm{CO}_{3}{ }^{2-}$ and $\mathrm{Cl}^{-}$had a strong influence on $\mathrm{Pb}$ speciation in solution. Formation of $\mathrm{Pb}-\mathrm{Cl}$ complexes can be observed at the highest $\mathrm{Pb}$ concentrations, and $\mathrm{Pb}-\mathrm{SO}_{4}{ }^{2-}$ at the lowest $\mathrm{pH}$ values. In the soil solution with the lowest $\mathrm{Pb}$ concentrations (at $\mathrm{pH}=8.25), 100 \%$ of the $\mathrm{Pb}$ was bound to $\mathrm{CO}_{3}{ }^{2-}\left(\mathrm{PbCO}_{3}(\mathrm{aq})\right.$ and $\left.\mathrm{Pb}\left(\mathrm{CO}_{3}\right)_{2}{ }^{2}\right)$, (Table $\mathrm{S} 1$ ).

The highest $\mathrm{Na}$ concentration in soil solution $(33,101$ $\mathrm{mg} \mathrm{kg}^{-1}$ ) corresponded to the lowest $\mathrm{pH}(6.0)$ at the site. $\mathrm{Na}$ was present mainly as a free ion $\left(\mathrm{Na}^{+}=97 \%\right)$ and in minor proportion was associated with $\mathrm{Cl}^{-}, \mathrm{CO}_{3}{ }^{-}$and $\mathrm{OH}^{-}$. The lowest sodium concentration was observed at the higher $\mathrm{pH}(8.5)$ : The free ion was predominant and the second species was $\mathrm{Na}$ associated to $\mathrm{Cl}^{-}, \mathrm{CO}_{3}{ }^{2-}$ and $\mathrm{PO}_{4}{ }^{3-}$.

\section{Discussion}

\section{Soil fertility, $\mathrm{pH}$ and salinity}

Low concentrations of $\mathrm{N}\left(0\right.$ to $5 \mathrm{mg} \mathrm{kg}^{-1}$ ) and $\mathrm{OM}(1.7 \%)$ showed poor soil fertility [25]. Therefore, it is needed to amend soil to support plant growth. The soil was alkaline $(\mathrm{pH}$ up to 9.4, Table 1) despite the parent material of the area (welded tuff and volcanic ashes) [26]. High concentrations of $\mathrm{Cl}^{-}$at the site $\left(8,050 \mathrm{mg} \mathrm{kg}^{-1}\right.$; Table 1$)$ increase $\mathrm{pH}$, apparently because $\mathrm{Cl}^{-}$replaces $\mathrm{OH}^{-}$ions on positively charged sites of soil particles, and $\mathrm{OH}^{-}$remains free [27]. High $\mathrm{Na}$ concentrations $\left(33,101 \mathrm{mg} \mathrm{kg}^{-1}\right)$ can also contribute to alkalinizing the soil.

The source of $\mathrm{Na}$ is probably for the use of $\mathrm{NaOH}$ to neutralize $\mathrm{H}_{2} \mathrm{SO}_{4}$ in the slurry to $\mathrm{Na}_{2} \mathrm{SO}_{4}$ during the $\mathrm{SO}_{4}{ }^{2-}$ recuperationin $\mathrm{LAB}$ recycling [28]. Sodium bicarbonate $\left(\mathrm{Na}_{2} \mathrm{CO}_{3}\right)$ is used to transform $\mathrm{PbSO}_{4}$ to $\mathrm{PbCO}_{3}$ [29]. These processes also explain the high $\mathrm{SO}_{4}^{2-}$ concentrations (up to $47,130 \mathrm{mg} \mathrm{L}^{-1}$, Table 1). Inadequate management of old batteries and $\mathrm{Na}$ compounds used for recycling and scant disposal of residues were performed by the LABR factory which operated at the site. Furthermore, it is well known that $\mathrm{Na}^{+}$excess promotes soil particles deflocculation and breakdown of aggregates [14]. Particle dispersion influences $\mathrm{Pb}$ mobilization by wind or rain which may easily transport the soil particles.

Phosphorus concentrations (4.1-7.2 $\left.\mathrm{mg} \mathrm{L}^{-1}\right)$ were above the typical soil concentrations ( 0.05 to $\left.0.5 \mathrm{mg} \mathrm{L}^{-1}\right)$ [30]. Similarly, plant available $\mathrm{PO}_{4}{ }^{3-}$ concentration (19 to 1,354 $\mathrm{mg} \mathrm{kg}^{-1}$ ) were also excessive (>50 mg kg-1) [30]. These concentrations may be due to the use of $\mathrm{H}_{3} \mathrm{PO}_{4}$ as the electrolyte in some batteries. Other important parameters concerning soil salinity are SAR and PAR. At the LABR site, these parameters were above recommended values (Table 1 ). High SAR values suggest that there is not enough $\mathrm{Ca}$ and $\mathrm{Mg}$ to compete with $\mathrm{Na}$ on the exchange surfaces in the soil [15]. That means $85 \%$ of the samples had SAR > 102, which is the maximum value proposed for very tolerant crops [31]. Moreover, PAR gives 

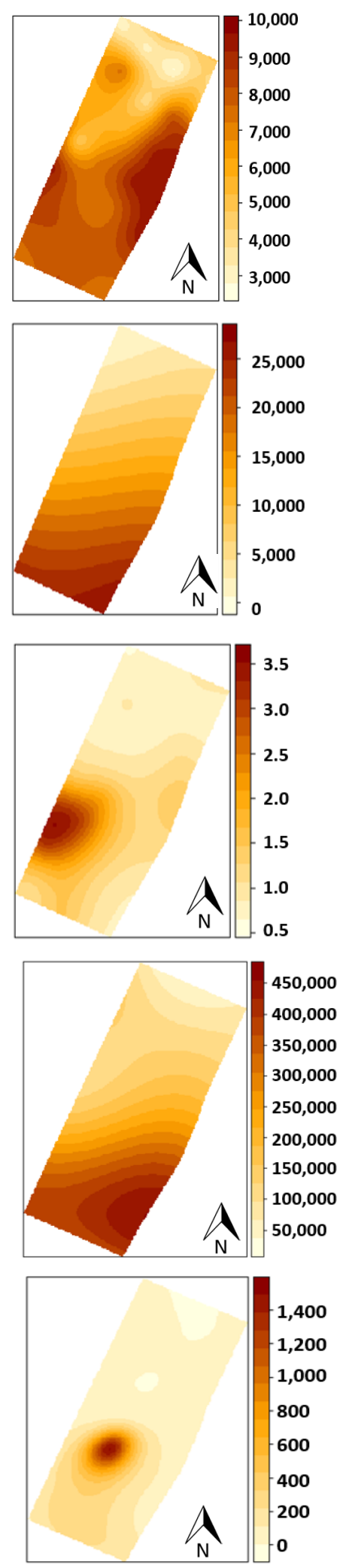
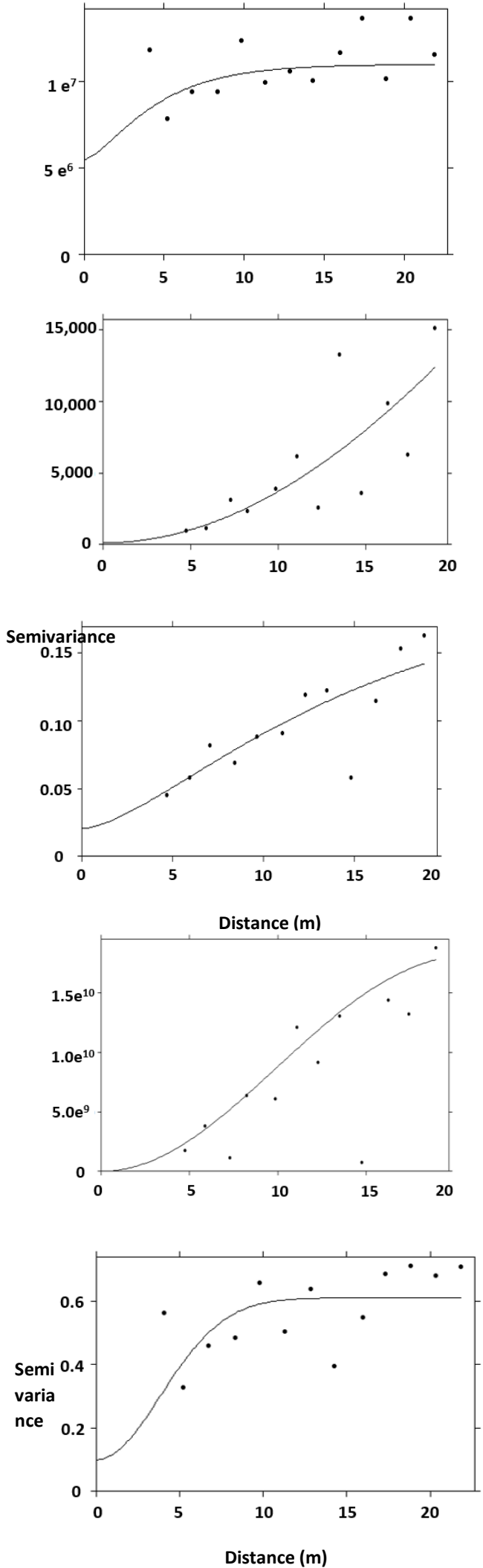

Figure 1: Spatial distribution of a) DTPA-TEA-CaCl extractable $\mathrm{Pb}$; b) exchangeable $\mathrm{Pb}$; c) water-soluble $\mathrm{Pb}$; d) total Pb and; e) DTPATEA- $\mathrm{CaCl}_{2}$ extractable $\mathrm{Cu}$. Colors in right bars represent the concentration $\left(\mathrm{mg} \mathrm{kg}^{-1}\right)$. The semivariograms are shown at the right side; $x$-axis represents the distance in meters and $y$-axis the semivariance (some semivariances correspond to transformed values to achieve assumptions). 
Citation: Carrillo-González R, Ruiz-Olivares A, González-Chávez MCA, et al. (2019) A Defunct Lead-Acid Battery Recycling May Lead Strong Soil Pollution: A Case of Study in Mexico. J Soil Water Sci 3(1):75-83

\section{Total metal concentrations}

Total concentrations of $\mathrm{Pb}, \mathrm{Cu}, \mathrm{Cd}$, and $\mathrm{Ni}$ in the LABR soil were up to 8,882, 50, 29 and five times higher, respectively than values referenced by Kabata-Pendias [32] for agricultural lands (Table 2). Possibly, high $\mathrm{Cu}, \mathrm{Cd}$ and $\mathrm{Ni}$ concentrations (up to 3911, 57 and $408 \mathrm{mg} \mathrm{kg}^{-1}$, respectively) come from alloys, batteries grids, and poles. In the same way, total $\mathrm{Pb}$ concentrations (up to $444,105 \mathrm{mg} \mathrm{kg}^{-1}$ ) exceeded regulatory limits of the country by 27 - 1110 times. The thresholds for residential land use in the USA range from 500 to $1000 \mathrm{mg}$ $\mathrm{kg}^{-1}$. While in Canada this is $375 \mathrm{mg} \mathrm{kg}^{-1}$, in The Netherlands is between 50 to $600 \mathrm{mg} \mathrm{kg}^{-1}$ and in England is $500 \mathrm{mg} \mathrm{kg}^{-1}$ [33].

Hence, total $\mathrm{Pb}$ concentrations at LABR soil are comparable with soils polluted by LABR in other regions of the world. Some of the most polluted sites have up to $400,000 \mathrm{mg} \mathrm{kg}^{-1}$ $(40 \%)$ of $\mathrm{Pb}[5,7]$. Similarly, Mohammed, et al. [4] found a soil containing up to $70 \%$ of $\mathrm{Pb}$. Wasay, et al. [34] observed 24,600 $\mathrm{mg} \mathrm{kg}^{-1}(2.46 \%)$ of $\mathrm{Pb}$ in soil due to the disposal of wastes of a LABR in Canada. In the same way, Yeh, et al. [35] reported a value of $3,590 \mathrm{mg} \mathrm{kg}^{-1} \mathrm{~Pb}$ in soil near a LABR factory in Taiwan. Rodríguez, et al. [36] found $1,050 \mathrm{mg} \mathrm{kg}^{-1}$ of $\mathrm{Pb}$ total concentration near a LABR facility in Argentina. Total soil $\mathrm{Pb}$ concentrations in LABR site makes necessary intervention to reduce the risk for public health and environmental damage.

The observed total $\mathrm{Pb}, \mathrm{Cu}, \mathrm{Ni}, \mathrm{Cd}$ and $\mathrm{Zn}$ concentrations in LABR soil suggest the impact of the free recycling process and inadequate waste management from this factory. Furthermore, the spatial total $\mathrm{Pb}$ distribution (Figure 1a) shows that the south zone of the site was the most polluted. Probably used slurry was disposed of in this part of the terrain.

\section{Soil heavy metals fractionation}

High $\mathrm{Pb}_{\mathrm{EX}}$ concentrations in the soil (up to $284,580 \mathrm{mg} \mathrm{kg}^{-1}$; Table 2) makes this metal the main risk in the site. The major $\mathrm{Pb}$ proportion was found in an exchangeable form (44 to 97\%). In another soil affected by LABR, Rodríguez, et al. [36], found up to $640 \mathrm{mg} \mathrm{kg}^{-1}$ of $\mathrm{Pb}_{\mathrm{EX}}$ at approximately $100 \mathrm{~m}$ away from a LABR facility. The potential mobile fraction (PMF) of lead was between 5.7 and $59.3 \%$, which suggested easy enter to the food chain.

Organic matter content, available $\mathrm{SO}_{4}{ }^{2-}(0.528, \mathrm{p}=0.024)$ and $\mathrm{PO}_{4}^{3-}(0.749, \mathrm{p}=0.001)$ concentrations were correlated positively with $\mathrm{Pb}_{\mathrm{Ex}}$. This can indicate the presence of available forms of $\mathrm{Pb}$ bound to the mentioned anions. The positive correlation between $\mathrm{Pb}_{\mathrm{EX}}$ and $\mathrm{OM}(0.641, \mathrm{p}=0.004)$ probably shows an electrostatic $\mathrm{Pb}-\mathrm{OM}$ association. The $\mathrm{OM}$ ability to sequestrate heavy metals may explain the correlation, which has been reported $[37,38]$ and can also explain the $\mathrm{Pb}$ concentrations observed as $\mathrm{Pb}_{\text {SOM }}$ (up to $7,506 \mathrm{mg} \mathrm{kg}^{-1}$ ) and $\mathrm{Pb}_{\text {wom }}$ (up to $73,642 \mathrm{mg} \mathrm{kg}^{-1}$ ). A Pb proportion was found as $\mathrm{Pb}_{\mathrm{FeMn}}$ (up to $21 \%$ of the total $\mathrm{Pb}$ ). The behavior of heavy metals with stable oxidation states depends indirectly on Fe compounds $[27,39]$. $\mathrm{Pb}$ may be adsorbed on the Fe and $\mathrm{Mn}$ oxides surfaces $[40,41]$. Pb fixation on oxides reduces $\mathrm{Pb}_{\mathrm{Ex}}$ concentration in the LABR soil.

Regarding Cu fractionation, the negative correlation found between $\mathrm{OM}$ and $\mathrm{Cu}_{\mathrm{EX}}(-0.71, \mathrm{p}=0.001)$ can be explained in terms of the high affinity of $\mathrm{Cu}$ by $\mathrm{OM}$. $\mathrm{Cu}$ is strongly associated, so $\mathrm{Cu}$ electrostatically retained decreased. The PMF was lower than $20.6 \%$. Other metals found in high concentration were $\mathrm{Zn}_{\mathrm{EX}}\left(1,984 \mathrm{mg} \mathrm{kg}^{-1}\right) \mathrm{Pb}_{\mathrm{EX}}\left(284,580 \mathrm{mg} \mathrm{kg}^{-1}\right) \mathrm{Ni}_{\mathrm{EX}}(63 \mathrm{mg}$ $\left.\mathrm{kg}^{-1}\right)$ and $\mathrm{Cd}_{\mathrm{Ex}}\left(11 \mathrm{mg} \mathrm{kg}^{-1}\right.$; Table 2). The PMF was also low (2.8 to $17.2 \%)$. Cadmium is considered a very hazardous metal due to its toxicity; but, an important proportion of Cd is associated to OM: $\mathrm{Cd}_{\text {som }}$ (up to $37 \%$ ), $\mathrm{Cd}_{\text {wom }}$ (up to $29 \%$ ), which ameliorates the potential effects of $\mathrm{Cd}$. In this soil the PMF was high (4.1 to $39.8 \%$ ). Similarly, $\mathrm{Ni}$ concentrations bound to $\mathrm{OM}\left(\mathrm{Ni}_{\text {wom }}\right.$ up to $62 \mathrm{mg} \mathrm{kg}^{-1}$ and $\mathrm{Ni}_{\text {som }}$ up to $7 \mathrm{mg} \mathrm{kg}^{-1}$ ) may contribute to the depletion of $\mathrm{Ni}_{\mathrm{EX}}$ concentrations.

Furthermore, heavy metals concentrations bound to $\mathrm{Fe}$ and $\mathrm{Mn}$ oxides were up to $21 \%, 63 \%, 46 \%, 40 \%$ and $46 \%$ of their total concentrations for $\mathrm{Pb}, \mathrm{Cu}, \mathrm{Ni} \mathrm{Zn}, \mathrm{Cd}$ and $\mathrm{Ni}$ respectively (Table 2 ). Apparently, Fe and Mn oxides may be contributing to heavy metal fixation in LABR site, which has been reported before [42].

\section{DTPA-extractable metals}

A similar spatial pattern of Pb (DTPA-extractable, extractable, water-soluble and total) and DTPA-extractable $\mathrm{Cu}$ (Figure 1) shows that south part of the site was the most affected by heavy metal pollution. Possibly due that to the slurry disposal was performed at the south side of the terrain.

The negative correlation found between $\mathrm{Pb}$ bioavailability index and OM content $(-0.570, p=0.021)$ may be due to the influence of $\mathrm{OM}$ on $\mathrm{Pb}$ bioavailability in LABR soil. Lead can be strongly adsorbed by $\mathrm{OM}$ and fixed as non-extractable forms or complexed with humic substances [43]. The addition of organic amendments to the soil may be a strategy to reduce $\mathrm{Pb}$ availability. Nevertheless high DTPA-extractable $\mathrm{Pb}$ concentrations are observed in the LABR site; which may be due to the saturation of $\mathrm{OM}$ adsorbent sites.

\section{$\mathrm{Pb}$ and $\mathrm{Na}$ chemical speciation in the soil solution}

Oxidizing (ORP: 300-600 mV; Table 1) and alkaline $(\mathrm{pH}>$ 7.4) conditions were predominantly observed in soil samples. Although the presence of $[\mathrm{PbOH}]^{+}$and $\left[\mathrm{PbO}_{2}\right]$ species [43] in LABR soil solution was expected. The $\mathrm{pH}$ only allows the $\mathrm{PbOH}^{+}$species (3.51\% of the total $\mathrm{Pb}$ in solution) in the paste saturation extract (Table S1).

The $\mathrm{Pb}$ concentration in soil solution was low the significant proportion of this metal was in the saturation paste extract (up to $85 \%$ of the $\mathrm{Pb}$ in solution) remained as a free divalent ion $\left(\mathrm{Pb}^{2+}\right)$. Other chemical species such as $\mathrm{PbOH}^{+}$, $\mathrm{Pb}\left(\mathrm{CO}_{3}\right)_{2}{ }^{2-}, \mathrm{Pb}(\mathrm{OH})_{2}(\mathrm{aq})$ and $\mathrm{Pb}\left(\mathrm{SO}_{4}\right)^{2-}$ were in minor concentrations. The occurrence of different $\mathrm{Pb}$ species is related to $\mathrm{Pb}$ mobility in soil. For instance, Weng [44] found that $\mathrm{Pb}^{2+}$ is less adsorbed on soils than $\mathrm{Pb}(\mathrm{OH})^{+}$. In the same way, Nedwed and Clifford [34] mentioned that $\mathrm{CO}_{3}{ }^{2-}$ or $\mathrm{CaO}$ could lead to the formation of $\mathrm{Pb}_{3}\left(\mathrm{CO}_{3}\right)_{2}(\mathrm{OH})_{2}, \mathrm{PbCO}_{3}$ or $\mathrm{Pb}$ $\mathrm{SO}_{4}\left(\mathrm{CO}_{3}\right)_{2}(\mathrm{OH})_{2}$; these species could reduce $\mathrm{Pb}$ mobility. In LABR site, $\mathrm{CO}_{3}{ }^{2-}$ was found in all samples and $\mathrm{Pb}$ associates with the mentioned anion at high $\mathrm{pH}$ (8.25 and 9.38; Supplementary Table 1). In contrast, in the soil with the lowest 
Citation: Carrillo-González R, Ruiz-Olivares A, González-Chávez MCA, et al. (2019) A Defunct Lead-Acid Battery Recycling May Lead Strong Soil Pollution: A Case of Study in Mexico. J Soil Water Sci 3(1):75-83

$\mathrm{pH}$ (6.05), $\mathrm{Pb}$ was associated predominantly to $\mathrm{SO}_{4}{ }^{2-}(55.76 \%$ and $39.27 \%$ of the total $\mathrm{Pb}$ in the solution for $\mathrm{Pb}\left(\mathrm{SO}_{4}\right)^{2-}$ and $\mathrm{PbSO}_{4(\text { aq) }}$ respectively). However, despite high $\mathrm{SO}_{4}{ }^{2-}$ concentration in saturation paste extract $\left(47,130 \mathrm{mg} \mathrm{kg}^{-1}\right)$, low concentrations of $\mathrm{Pb}\left(\mathrm{SO}_{4}\right)^{2-}$ and $\mathrm{PbSO}_{4}(\mathrm{aq})(1.27$ and $0.89 \mathrm{mg}$ $\mathrm{kg}^{-1}$, respectively) may be explained by the low solubility of compounds formed between $\mathrm{Pb}$ and $\mathrm{SO}_{4}^{2-}$; and $\mathrm{Pb}$ competition with $\mathrm{Ca}^{2+}, \mathrm{Na}^{+}$and $\mathrm{K}^{+}$, cations with more affinity for $\mathrm{SO}_{4}{ }_{4}^{2-}$. Other possible reaction of $\mathrm{SO}_{4}^{2-}$ is the reduction as sulfides, which can sequestrate heavy metals. Adsorption and precipitation of $\mathrm{Pb}$ on $\mathrm{SO}_{4}{ }_{4}^{2-}$ compounds are important buffer mechanisms for fixation and controlling the migration of $\mathrm{Pb}$ [45]. The fractionation shows a high proportion of $\mathrm{Pb}$ bound to sulfides (PbS); up to $39 \%$ of the total.

Sodium ion was the predominant species in soil solution (Table S1), but $\mathrm{Na}$ associated with $\mathrm{CO}_{3}{ }^{2-}, \mathrm{SO}_{4}{ }^{2-}, \mathrm{PO}_{4}{ }^{3-}, \mathrm{Cl}^{-}$was also present. There is scarce information regarding the effect of $\mathrm{Na}$ on speciation in soils metal bioavailability. Ghallab and Usman [46] found increased concentrations of $\mathrm{Cd}$ in solution due to $\mathrm{NaCl}$ additions; apparently, $\mathrm{Cd}$ was displaced by $\mathrm{Na}$ from exchange surfaces. In LABR soil solution, $\mathrm{NaCl}$ was present in high concentration (up to $943.8 \mathrm{mg} \mathrm{L}^{-1}$ ). Hence, the influence of $\mathrm{Na}$ on heavy metals solubility should be further studied in LABR soil.

High $\mathrm{Na}^{+}, \mathrm{Cl}^{-}, \mathrm{PO}_{4}{ }^{3-}$ and $\mathrm{SO}_{4}{ }^{2-}$ concentrations (Table 1 ) increase soil solution ionic strength (IS) in the LABR site. The IS ranged from 0.005 to $1.185 \mathrm{M}$ values. While, in non-polluted soils, the IS ranged from 0.003 to $0.016 \mathrm{M}$ [47]. Ionic strength leads to an increment of metal solubility because cations compete with metals for exchange sites and formation of metal-salt species with no charge or negative charge such as metal $-\mathrm{Cl}_{2}{ }^{\circ}$, metal $-\mathrm{Cl}_{3}{ }^{-}$and metal $-\mathrm{Cl}_{4}{ }^{-}$complexes [48]. At the LABR soil, some $\mathrm{Cl}$ - metal species were found (Table S1). Hence, $\mathrm{Na}^{+}, \mathrm{Cl}^{-}, \mathrm{PO}_{4}{ }^{3-}$ and $\mathrm{SO}_{4}{ }^{2-}$ could contribute to metal solubility.

\section{Conclusions}

The LABR activities at this site resulted in a heavily polluted soil due to: 1) Very high total Pb concentrations; which makes this site similar to others reported in the literature as the most world polluted sites by $\mathrm{Pb} ; 2$ ) Elevated total concentrations of $\mathrm{Cu}$. High DTPA-extractable and exchangeable concentrations of $\mathrm{Pb}$ and $\mathrm{Cu}$ are very risky for plant establishment; and 3) Alkaline conditions and high concentrations of plant available $\mathrm{SO}_{4}{ }^{2-}, \mathrm{PO}_{4}{ }^{3-}$ in the soil solution, as well as water-soluble $\mathrm{Cl}^{-}$and $\mathrm{Na}^{+}$. These hazards represent a potential risk to human health and the environment. One possible method to reduce concentrations of salts and heavy metals from solution is by leaching the soil. However, the process might demand large volumes of water and the resulting leachate will require treatment.

The fertility of the soil should be improved, due to the low $\mathrm{N}$ concentration. An organic addition could improve physical and chemical soil conditions, and fertility, besides could reduce availability and mobility of heavy metal. At this time, long time phytoremediation and biofuel experiments in the LABR site are being performed taking into account the information provided by the present research.

\section{Acknowledgments}

The facilities to access the LABR area from PROFEPA from the State of Mexico and Tepetlaoxtoc Municipality are recognized. Partial financial support work was provided by CONACYT-Mexico as a Masters Fellowship.

\section{References}

1. Q Zhang (2013) The current status on the recycling of lead-acid batteries in China. Int J Electrochem Sci 8: 6457-6466.

2. EPA (Environmental Protection Agency) (1991) States' Efforts to Promote Lead-Acid Battery Recycling, Environmental Protection Agency.

3. MA Kreusch, MJJS Ponte, HA Ponte, et al. (2007) Technological improvements in automotive battery recycling. Resour Conserv Recycl 52: 368-380.

4. TI Mohammed, I Chang-Yen, I Bekele (1996) Lead pollution in East Trinidad resulting from recycling and smelting activities, Environ. Geochem. Health 18: 123-128.

5. Blacksmith Institute, Green Cross Switzerland (2013) The World's Worst Pollution Problems: Assessing Health Risks at Hazardous Waste Sites.

6. ATSDR (2017) Priority list of hazardous substances.

7. Pure Earth/Green Cross Switzerland, (2015) Top ten: Toxic pollution problems. Green Cross Switzerland and Pure Earth, New York.

8. R Gilbert (1987) Statistical methods for environmental pollution monitoring. John Wiley \& Sons Inc.

9. TS Light (1972) Standard solution for redox potential measurements. Anal Che 44: 1038-1039.

10. SR Olsen, LE Sommers, (1982) Phosphorus. In: CA Black, Part 2: Chemical and Microbiological Properties. Agronomy 9, Methods of Soil Analysis, 1159.

11. DR Walker (1972) Soil sulfate I. Extraction and measurement. Can J Soil Sci 52: 253-260.

12. JM Bremner (1965) Inorganic forms of nitrogen. in: CA Black (Edn) Agronomy 9. Methods of Soils Analysis. Part 2: Chemical and Microbiological Properties, American Society of Agronomy and American Society for Testing and Materials, 1179-1237.

13. RH Loeppert, DL Suarez (1996) Carbonate and gypsum. In: D.L. Sparks, Methods of soil analysis. Part 3 Chemical methods, SSSA Book Series, Madison, 437-474.

14. DL Rowell (1994) Soil Science: Methods and Applications. Longman Scientific \& Technical/John Wiley \& Sons.

15. USDA (1954) Diagnosis and Improvement of Saline and Alkaline Soils. Agriculture United States Department of Agriculture.

16. US EPA (1986) Method 9038: Sulfate (Turbidimetric).

17. BS Chauhan (2013) Engineering Chemistry (MTU). Laxmi Publications.

18. HD Chapman, PF Pratt (1986) Métodos de Análisis para Suelos. Plantas y Aguas, Trillas.

19. US EPA (1996) Method 3050B: Acid digestion of sediments, sludges and soils. Environmental Protection Agency.

20. WL Lindsay, WA Norvell (1978) Development of a DTPA soil zinc, iron, manganese and copper. Soil Sci Soc Am J 42: 421-428. 
21. B Chen, X Shan Han, J Qian (1996) Bioavailability index for quantitative evaluation of plant availability of extractable soil trace elements. Plant Soil 186: 275-283.

22. F Pagnanelli, E Moscardini, V Giuliano, et al. (2004) Sequential extraction of heavy metals in river sediments of an abandoned pyrite mining area: Pollution detection and affinity series. Environ Pollut 132: 189-201.

23. $R$ Development Core Team (2015) R: A language and environment for statistical computing. The $\mathrm{R}$ fundation for Statistical Computing, Vienna, Australia.

24. P Marschner Z Rengel (2012) Nutrient Availability in Soils. (3 $3^{\text {rd }}$ edn) In: Marschner P, Marschner's Mineral Nutrition of Higher Plants. Elsevier Ltd, 315-330.

25. DE Smiles, CJ Smith (2004) A survey of the cation content of piggery effluents and some consequences of their use to irrigate soils. Aust J Soil Res 42: 231-246.

26. FJ Cortés (1970) Estudio pedogenético y distribución de los vertisoles en la cuenca de México. Engeneer thesis. Escuela Nacional de Agricultura, México.

27. G Xu, Magen H, Tarchitzky J, et al. (2006) Advances in chloride nutrition. Adv Agron 68: 97-150.

28. K Ramus, P Hawkins (1993) Lead/acid battery recycling and the new Isasmelt process. J Power Sour 42: 299-313.

29. M Stevenson (2004) Recovery and Recycling of Lead-Acid Batteries. in: PT Moseley, CDP Garche, DAJ Rand, ValveRegulated Lead-Acid Batteries. Elsevier, 491-512.

30. DA Horneck, DM Sullivan, JS Owen, (2011) Soil Test Interpretation Guide. Oregon State University. Extension Service.

31. H Hazelton, B Murphy (2007) Interpreting Soil Test Results: What Do All the Numbers Mean? ( $2^{\text {nd }}$ edn), CSIRO Publishing, Oxford.

32. A Kabata-Pendias (2011) Trace Elements in Soils and Plants. (4 ${ }^{\text {th }}$ edn), CRC Press/Taylor \& Francis Group, USA.

33. DA Nedwed, A Clifford (1998) A survey of lead battery recycling sites and soil remediation processes. Waste Manag 17: 257-269.

34. SA Wasay, WJ Parker, PJ Van Geel (2001) Contamination of a calcareous soil by battery industry wastes I Characterization. Can J Civ Eng 28: 341-348.

35. CY Yeh, HY Chiou, RY Chen, et al. (1996) Monitoring lead pollution near a storage battery recycling plant in Taiwan, Republic of China. Arch Environ Contam Toxicol 30: 227-234.

36. JH Rodríguez, MJ Salazar, L Steffan, et al. (2014) Assessment of
$\mathrm{Pb}$ and $\mathrm{Zn}$ contents in agricultural soils and soybean crops near to a former battery recycling plant in Córdoba, Argentina. J Geochemical Explor 145: 129-134.

37. Y Yin, CA Impellitteri, SJ You, et al. (2002) The importance of organic matter distribution and extract soil: Solution ratio on the desorption of heavy metals from soil. Sci Total Environ 287: 107119.

38. YF Zhou, RJ Haynes, R Naidu (2012) Use of inorganic and organic wastes for in situ immobilization of $\mathrm{Pb}$ and $\mathrm{Zn}$ in a contaminated alkaline soil. Environ Sci Pollut Res 19: 1260-1270.

39. YN Vodyanitskii (2010) The role of iron in the fixation of heavy metals and metalloids in soils : A Review of Publications. Eurasian Soil Sci 43: 519-532.

40. A Suda, T Makino (2016) Functional effects of manganese and iron oxides on the dynamics of trace elements in soils with a special focus on arsenic and cadmium: A review. Geoderma 270: 68-75.

41. MD Royer, A Selvakumar, R Gaire (1992) Control technologies for remediation of contaminated soil and waste deposits at superfund lead battery recycling sites. J Air Waste Manage Assoc 42: 970-980.

42. L Wang, B Yan, L Zhu, et al. (2015) The effect of reclamation on the distribution of heavy metals in saline-sodic soil of Songnen Plain, China. Environ Earth Sci 73: 1083-1090.

43. N Takeno (2005) Atlas of Eh-pH diagrams: Intercomparison of thermodynamic databases, Natl Inst Adv Ind Sci Technol.

44. $\mathrm{CH}$ Weng (2004) Modeling $\mathrm{Pb}$ (II) adsorption onto sandy loam soil. J Colloid Interface Sci 272: 262-270.

45. PE Jensen, LM Ottosen, AJ Pedersen (2006) Speciation of Pb in industrially polluted soils. Water Air Soil Pollut 170: 359-382.

46. A Ghallab, ARA Usman (2007) Effect of sodium chloride-induced salinity on phyto-availability and speciation of $\mathrm{Cd}$ in soil solution. Water Air Soil Pollut 185: 43-51.

47. CD Edmeades, DM Wheeler, E Clinton (1985) The chemical composition and ionic strength of soil solutions from New Zealand topsoils. Aust J Soil Res 23: 151-165.

48. G Petruzzelli, G Guidi, L Lubrano (1985) Ionic strength effect on heavy metal adsorption by soil. Commun Soil Sci Plant Anal 16: 971-986.

49. M Radojević, VM Bashkin (1999) Practical Environmental Analysis. Royal Society of Chemistry, Cambridge. 


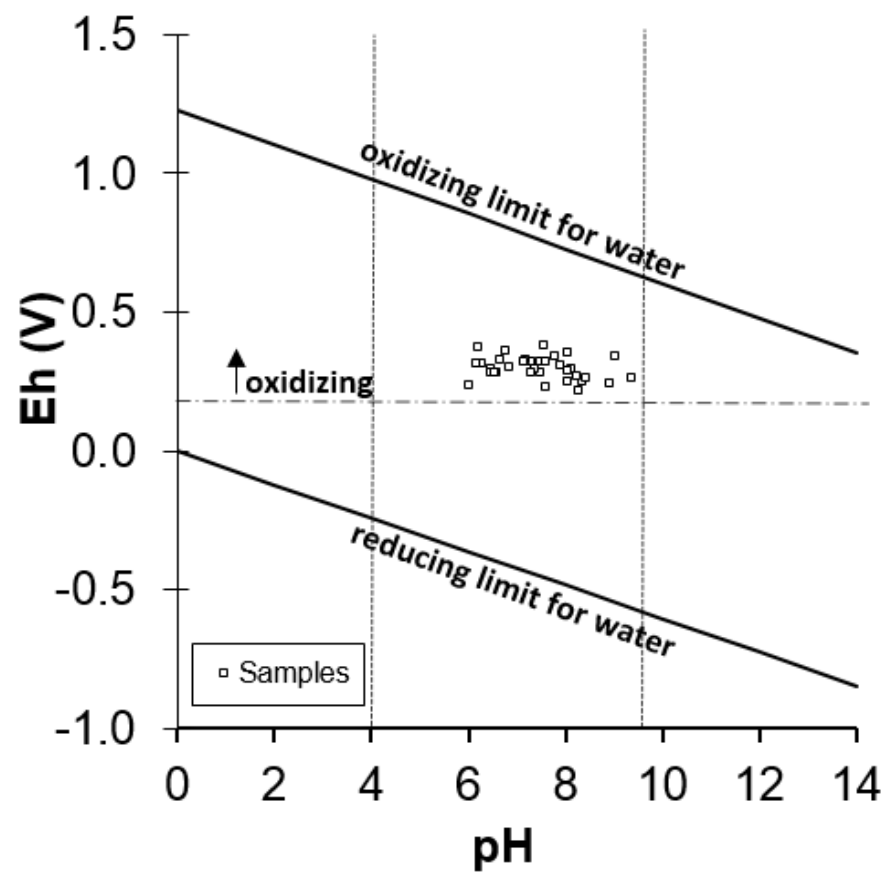

Figure S1: Curves of $\mathrm{pH}$-Eh (oxidation-reduction) and values observed in saturation paste extracts (soil solution) from a defunct LABR site. Vertical dotted lines represent the range of $\mathrm{pH}$ commonly found in soils [49].

Table S1: Speciation $\mathrm{Pb}$ and $\mathrm{Na}$ for contrasting conditions of paste saturation extracts from the defunct LABR soil.

\begin{tabular}{|c|c|c|}
\hline Species & $\begin{array}{l}\text { Concentration in } \\
\text { solution }\left(\mathrm{mg} \mathrm{L}^{-1}\right)\end{array}$ & $\begin{array}{l}\text { Percentage of the } \\
\text { total in solution (\%) }\end{array}$ \\
\hline \multicolumn{3}{|c|}{ Highest $\mathrm{Pb}$ concentration $\quad 4.65 \mathrm{mg} \mathrm{L}^{-1}, \mathrm{pH}=6.18$} \\
\hline $\mathrm{Pb}^{2+}$ & 4.00 & 85.97 \\
\hline $\mathrm{PbCl}^{+}$ & 0.62 & 13.34 \\
\hline $\mathrm{PbCl}_{2}(\mathrm{aq})$ & 0.03 & 0.7 \\
\hline \multicolumn{3}{|c|}{ Lowest $\mathrm{Pb}$ concentration $\quad 0.024 \mathrm{mg} \mathrm{L}^{-1}, \mathrm{pH}=8.25$} \\
\hline $\mathrm{PbCO}_{3}(\mathrm{aq})$ & $2.14 \mathrm{e}^{-2}$ & 90.2 \\
\hline $\mathrm{Pb}\left(\mathrm{CO}_{3}\right)_{2}^{2-}$ & $2.32 \mathrm{e}^{-3}$ & 9.8 \\
\hline \multicolumn{3}{|c|}{$\mathrm{Pb}$ in the highest $\mathrm{pH} \quad 2.65 \mathrm{mg} \cdot \mathrm{L}^{-1}, \mathrm{pH}=9.38$} \\
\hline $\mathrm{Pb}\left(\mathrm{CO}_{3}\right)_{2}^{2-}$ & 1.39 & 52.41 \\
\hline $\mathrm{PbCO}_{3}(\mathrm{aq})$ & 1.09 & 41.10 \\
\hline $\mathrm{PbOH}^{+}$ & $9.31 \mathrm{e}^{-2}$ & 3.51 \\
\hline $\mathrm{Pb}(\mathrm{OH})_{2}(\mathrm{aq})$ & $7.310 \mathrm{e}^{-2}$ & 2.76 \\
\hline $\mathrm{Pb}^{2+}$ & $3.02 \mathrm{e}^{-3}$ & 0.11 \\
\hline $\mathrm{PbHCO}_{3}^{+}$ & $2.81 \mathrm{e}^{-3}$ & 0.10 \\
\hline \multicolumn{3}{|c|}{$\mathrm{Pb}$ in the lowest $\mathrm{pH} 2.274 \mathrm{mg} \mathrm{L}^{-1}, \mathrm{pH}=6.05$} \\
\hline
\end{tabular}

\begin{tabular}{|c|c|c|}
\hline $\mathrm{Pb}\left(\mathrm{SO}_{4}\right)^{2-}$ & 1.27 & 55.79 \\
\hline $\mathrm{PbSO}_{4}(\mathrm{aq})$ & $8.93 \mathrm{e}^{-1}$ & 39.27 \\
\hline $\mathrm{Pb}^{2+}$ & $9.16 \mathrm{e}^{-2}$ & 4.03 \\
\hline $\mathrm{PbCl}^{+}$ & $7.88 \mathrm{e}^{-3}$ & 0.35 \\
\hline $\mathrm{PbHCO}_{3}^{+}$ & $1.27 \mathrm{e}^{-2}$ & 0.56 \\
\hline \multicolumn{3}{|c|}{ At the highest $\mathrm{Na}$ concentration $33.101 \mathrm{mg} \mathrm{L}^{-1}, \mathrm{pH}=6.05$} \\
\hline $\mathrm{Na}^{+}$ & 32.730 & 97.18 \\
\hline $\mathrm{NaCl}(\mathrm{aq})$ & 943.8 & 2.80 \\
\hline $\mathrm{NaHCO}_{3}(\mathrm{aq})$ & 3.8 & 0.01 \\
\hline $\mathrm{NaCO}_{3}^{-}$ & $1.7 \mathrm{e}^{-3}$ & $<0.01$ \\
\hline $\mathrm{NaOH}(\mathrm{aq})$ & $1.3 e^{-4}$ & $<0.01$ \\
\hline \multicolumn{3}{|c|}{ At the lowest Na concentration } \\
\hline $\mathrm{Na}^{+}$ & 73.8 & 98.98 \\
\hline $\mathrm{NaHCO}_{3}(\mathrm{aq})$ & 0.4 & 0.53 \\
\hline $\mathrm{NaHPO}_{4}^{-}$ & $1.70 \mathrm{e}^{-1}$ & 0.22 \\
\hline $\mathrm{NaCl}(\mathrm{aq})$ & 0.1 & 0.13 \\
\hline $\mathrm{NaCO}_{3}^{-}$ & $8.20 e^{-2}$ & 0.11 \\
\hline $\mathrm{NaH}_{2} \mathrm{PO}_{4}(\mathrm{aq})$ & $3.80 \mathrm{e}^{-3}$ & $<0.01$ \\
\hline
\end{tabular}

aq: Aqueous species.

DOI: $10.36959 / 624 / 432$ 